\title{
POLIOMYELITIS IN INFANTS UNDER THE AGE OF 6 MONTHS
}

\author{
BY \\ A. A. McCONNELL \\ From the Northern Ireland Fever Hospital, Belfast
}

(RECEIVED FOR PUBLCATION SEPTEMBER 3, 1951)

Reported cases of poliomyelitis in infants under the age of 6 months are rare, especially in the British literature, none having been recorded since 1918 (Gunewardene, 1918). Aycock and Kramer (1930), on the basis of virus neutralization tests, suggested that the infrequency of cases under 1 year of age was due to the passive transmission of immune bodies through the placenta, and although only one group of workers (Ward, Horstmann and Melnick, 1946) have isolated the virus from the blood, one case of possible intrauterine infection was reported by Baskin, Soule and Mills (1950). This case in a 5-day-old infant is the youngest in the literature.

Mouton, Smillie and Bower in 1950 could find only 10 previously recorded cases of poliomyelitis under the age of 6 months and reported 10 more. Since then Baskin, Soule and Mills (1950) have reported two cases occurring in the neonatal period.

During the 1950 epidemic of poliomyelitis the disease occurred in 10 patients aged under 6 months out of a total of 243 cases of poliomyelitis admitted to the Northern Ireland Fever Hospital. The age incidence of the disease during this epidemic was more nearly that of the textbook description than in 1947 when none of 78 cases admitted was under 6 months of age. The age incidences in the two epidemics are compared in Table 1.

\section{Case Records}

These are summarized in Table 2.

Case 1: P. McD. A girl aged 2 months was admitted on the fourth day of her illness with a history of general apathy and refusal to feed. She had not been vaccinated nor had she been immunized against diphtheria or pertussis.

On examination she was slightly cyanosed and completely disinterested in her surroundings. There were no meningeal signs and the fontanelle was normal but there was a flaccid paralysis of both arms and the neck muscles. Limited weak movement of the legs occurred in response to painful stimuli, while the knee and ankle jerks were depressed. Breathing was entirely diaphragmatic and a few râles were audible at the base of the left lung. The cerebrospinal fluid (C.S.F.), which was under a slightly increased pressure, contained $80 \mathrm{mg}$. of protein and $52.5 \mathrm{mg}$. of sugar per $100 \mathrm{ml}$., while the cells numbered 114 per c.mm.

The child was nursed in an oxygen tent and the next day her colour had improved. Some movement of the hands was observed, but the arms and neck muscles remained paralysed and the left leg had become completely flaccid. Two days after admission, despite apparent improvement in the function of the intercostal muscles, the child died quite suddenly. A post-mortem examination was not performed.

Case 2: P. McV. A boy of 5 months was admitted on the seventh day of his illness. He had a history of vomiting and diarrhoea on the day of onset, followed three days later by head rolling and on the fourth day by

TABLE 1

Comparison of Age Incidences in Two Outbreaks of Polomyeltis in Northern Ireland

\begin{tabular}{|c|c|c|c|c|c|c|c|c|c|}
\hline $\begin{array}{c}\text { Age } \\
\text { (in years) }\end{array}$ & $0-\frac{1}{2}$ & $\frac{1}{2}-1$ & $1-3$ & $3-6$ & 6-9 & 9-12 & $12-20$ & $\begin{array}{c}\text { Over } \\
20\end{array}$ & Total \\
\hline 1947 & 0 & 2 & 11 & 15 & 10 & 7 & 13 & 20 & 78 \\
\hline 1950 & 10 & 16 & 74 & 42 & 34 & 11 & 28 & 28 & 243 \\
\hline
\end{tabular}


paralysis of both legs. He had not been vaccinated nor had he been immunized against diphtheria or pertussis.

On examination he was markedly irritable but showed no meningeal signs. Both legs and the right arm were paralysed, with loss of the tendon reflexes. There was limited weak movement of the left arm and hand. No abnormality of cranial nerve or respiratory muscle function was detected. The ear drums were healthy. The C.S.F. was clear and contained $80 \mathrm{mg}$. of protein and $50 \mathrm{mg}$. of sugar per $100 \mathrm{ml}$. and 31 cells per c.mm.

No spread of the paralysis occurred and 10 days after admission feeble movements of the toes were observed while strength returned quite rapidly to the left arm. On transfer to an orthopaedic hospital three months later the legs had shown no further improvement.

Case 3: J.H. A boy of 5 months was admitted on the twelfth day of his illness. He had a history of feverishness and irritability for five days followed by weakness of both legs. Vaccination had not been performed nor had he been immunized against diphtheria or pertussis.

On examination no meningeal signs were elicited. There was a complete flaccid paralysis of the right leg and well marked spasm of the gastrocnemius and quadriceps muscles of the left leg. The arms and cranial nerves were normal. The C.S.F. contained $50 \mathrm{mg}$. of protein and $60 \mathrm{mg}$. of sugar per $100 \mathrm{ml}$. and 56 cells per c.mm.

The left leg subsequently became flaccid and on discharge, four months later, no improvement had occurred apart from the return of a weak contraction in the right quadriceps.

Case 4: P.G. A girl of 3 months was admitted on the seventh day of her illness with a history of irritability for two days followed by weakness of the arms and neck muscles. The child had been successfully vaccinated in the left arm six weeks before the onset of the illness but had not been immunized against diphtheria or pertussis.

On examination there was a flaccid paralysis of both legs and the right arm. The left hand grip was strong but no movements could be elicited at the left elbow or shoulder joints. Painful stimuli caused weak flexion and extension of the toes but the tendon reflexes in the legs could not be elicited. The C.S.F. contained some traumatic blood. The supernatant fluid was clear and contained $70 \mathrm{mg}$. of protein and $60 \mathrm{mg}$. of sugar per $100 \mathrm{ml}$.

Movements returned slowly to all limbs, first to the right hand, then to the arms and finally to the legs. On discharge, three months later, the only residuum was weakness of the left shoulder.

Case 5: J.D. A boy of 5 months was admitted on the fifth day of his illness. He had been irritable, out of sorts and off his feeds, and was observed to have paralysis of the left arm. He had not been vaccinated nor had he been immunized against diphtheria or pertussis.

On examination the child was pale and irritable. There was a flaccid paralysis of the neck muscles, both arms and forearms. Finger movements were present in both hands and although the child was unable to sit up the legs appeared to be strong. The C.S.F. contained $40 \mathrm{mg}$. of protein and $52 \mathrm{mg}$. of sugar per $100 \mathrm{ml}$. and the cell count was 214 per c.mm.

Gradually all the paralysed muscles recovered and on discharge two months later the child was apparently normal.

Case 6: C.P. A girl of 4 months was admitted on the eighth day of her illness with a history of malaise, irritability and a weak cry. On the day of admission the left arm was noticed to be weak. She had not been vaccinated nor had she been immunized against diphtheria or pertussis.

On examination the child was irritable but meningeal signs were absent. Paralysis was limited to the left arm and shoulder girdle. A weak contraction was palpable in the left biceps. The C.S.F. contained $50 \mathrm{mg}$. of protein and $40 \mathrm{mg}$. of sugar per $100 \mathrm{ml}$. and 36 cells per c.mm.

The condition failed to respond to treatment, and on discharge two months later marked wasting of the left shoulder girdle had occurred.

Case 7: D.McF. A boy of 5 weeks was the heavier of premature twins born in a maternity hospital. He was discharged before his twin at the age of 3 weeks. Ten days later he developed fever, vomiting and constipation. On the fourth day of his illness the child was admitted to another hospital where he was treated with intramuscular penicillin and streptomycin. After 48 hours meningeal signs became evident and a lumbar puncture was performed. The C.S.F. contained $90 \mathrm{mg}$. of protein and $48 \mathrm{mg}$. of sugar per $100 \mathrm{ml}$., and 190 cells per c.mm. Following lumbar puncture he was transferred to the Northern Ireland Fever Hospital on the sixth day of his illness. He had not been vaccinated nor had he been immunized against diphtheria or pertussis.

On examination the child looked exhausted and had a weak persistent cry. No movement of the legs, right arm or intercostal muscles could be detected.

Although movements of the toes and left leg improved slightly the right leg wasted rapidly and contractures developed in both feet. The chest became grossly deformed as a result of the purely diaphragmatic breathing and after six months in hospital the child died of bronchopneumonia. No necropsy was carried out.

Case 8: M.W. A girl of 5 months was admitted on the seventh day of her illness having been feverish and irritable with vomiting and constipation. The child was breast-fed and had been successfully vaccinated three months previously but had not been immunized against diphtheria or pertussis.

On examination she was very irritable and had a mild thrush stomatitis. There was a flaccid paralysis of both legs and considerable weakness of the left arm, the tendon reflexes being absent. The C.S.F. contained $60 \mathrm{mg}$. of protein and 40 cells per c.mm., but the sugar content was not estimated.

After admission the paralysis spread to involve the abdominal muscles and the right arm, the fingers and 
wrists, however, escaping. At the time of discharge three months later the abdominal and both deltoid muscles were still paralysed and apart from weak contraction of the left quadriceps no improvement had occurred in the legs.

Case 9: R.C. A boy of 5 weeks was admitted on the fifth day of his illness with a history of pyrexia and failure to feed. He had had penicillin injections threehourly for $\mathbf{4 8}$ hours before admission but had not been vaccinated nor had he been immunized against diphtheria or pertussis.

On examination he had a flaccid paralysis of both legs and the right arm. The left arm was weak but the tendon reflexes were still present. The cranial nerves and muscles of respiration did not appear to be affected. The C.S.F. contained some traumatic blood, $200 \mathrm{mg}$. of protein and $48 \mathrm{mg}$. of sugar per $100 \mathrm{ml}$.

The paralysis did not spread but six months later little improvement had occurred. There was a weak flexion movement in both hips but otherwise the legs were flaccid and a complete paralysis of the right shoulder girdle persisted.

Case 10: M.McC. A boy of 16 days was admitted on the second day of his illness with a history of anorexia, the sudden onset of harsh breathing and twitching of the left side of the face. The birth at home had been uneventful and the child developed normally before the beginning of the illness.

On examination no meningeal signs were observed. Breathing was entirely diaphragmatic and the left side of the forehead twitched at long intervals. Muscle spasm was palpable in both legs but the arms were flaccid. The C.S.F. contained $100 \mathrm{mg}$. of protein per $100 \mathrm{ml}$. and 130 cells per c.mm.

The child was nursed in an oxygen tent and fed well from a pipette. His condition changed little during the next few days but later he was able to be nursed out of the tent. On the ninth day of illness, however, a convulsion occurred. This was controlled by general anaesthesia but the child died following two further convulsions three hours later.

A post-mortem examination was performed 14 hours after death by Dr. A. R. Crawford and the principal findings have been abstracted from her report:-

Macroscopically the only abnormalities detected were a few petechial haemorrhages beneath the endocardium of the left ventricle and a firm, deeply haemorrhagic area in the anterior papillary muscle of the left ventricle.

A microscopical examination gave the following picture:

SPINAL CORD. This showed pathological changes typical of anterior poliomyelitis. These were relatively mild in the thoracic cord but severe in both the lumbar and cervical enlargements.

Medilla. There were bilateral lesions in the medulla mostly in the area dorsal to the inferior olivary nucleus. At another level more recent lesions consisted of large areas of necrosis with some haemorrhage into them and lymphocytes cuffing the neighbouring vessels.

PoNs. Near the dorsal aspect the pons showed a large area of recent necrosis containing numerous small haemorrhages. In other parts of the sections there were small foci of cellular infiltration, lymphocytic cuffing of some vessels and chromatolysis of nerve cells.

Basal Ganglia. These also showed areas of recent necrosis and haemorrhage, the largest being about $5 \mathrm{~mm}$. in diameter.

Motor and Pre-motor Cortex. Sections showed only congestion and chromatolysis of some nerve cells.

Cerebellum. No pathological changes were seen.

HEART. Sections of the left auricle and left ventricle showed evidence of widespread myocardial damage. In the ventricle there were numerous areas of focal necrosis infiltrated by a few lymphocytes and large mononuclear cells. The tip of the papillary muscle was completely necrotic and full of recently extravasated blood cells.

The endocardium and pericardium appeared normal.

LuNGs. Sections of the lower lobes showed small areas of collapse. Some alveoli contained red blood cells and there were also groups of phagocytic cells with foamy cytoplasm. There was infiltration of the peribronchial interstitial tissue by lymphocytes and large mononuclear cells.

\section{Discussion}

Symptoms and Signs. The history of the onset of the illness obtained in these 10 cases is probably incomplete as the information was usually obtained several days after the children were admitted to hospital when the parents came to visit them. Nevertheless they are worthy of comment if only to stress their indefinite nature. Irritability and refusal to feed were the most common presenting symptoms. Vomiting, which occurred in three cases, constipation in two, and diarrhoea in one, have not previously been recorded as symptoms of poliomyelitis in this age group. Mouton, Smillie and Bower (1950), reporting 10 cases, commented that gastro-intestinal upsets were conspicuous by their absence.

Paralysis was observed by the parents in only four cases before admission.

Meningeal signs, so common in adult poliomyelitis, are seldom observed in the infant. In only one of the 10 cases in this series were they present on admission to hospital, but, as few of the cases were admitted early in the course of the disease, they may well have occurred during the initial stages.

Cases of poliomyelitis occurring in the neonatal period and associated with infection in the mother or immediate family have been recorded (Biermann and Piszczek, 1944; Baskin, Soule and Mills, 1950). In all these cases the presenting sign was pyrexia and other physical signs, apart from paralysis, were uncommon.

In this age group convulsions, at any stage of poliomyelitis, have not previously been reported 
TABLE 2

Summary of Case Records

\begin{tabular}{|c|c|c|c|c|c|c|}
\hline $\begin{array}{l}\text { Case } \\
\text { Number }\end{array}$ & Age & Sex & Symptoms & C.S.F. & Paralysis & Result \\
\hline 1 & 2 mths. & $\mathbf{F}$ & $\begin{array}{l}\text { Anorexia } \\
\text { Apathy }\end{array}$ & $\begin{array}{lc}\text { P } & 80 \\
\text { C } & 114 \\
\text { S } & 52 \cdot 5\end{array}$ & $\begin{array}{l}\text { Neck } \\
\text { Intercostals } \\
\text { Both arms } \\
\text { Left leg }\end{array}$ & Died 6th day \\
\hline 2 & 5 mths. & $\mathbf{M}$ & $\begin{array}{l}\text { Irritable } \\
\text { Vomiting }\end{array}$ & $\begin{array}{ll}P & 80 \\
C & 31 \\
\text { S } & 50\end{array}$ & $\begin{array}{l}\text { Arms } \\
\text { Trunk } \\
\text { Both legs }\end{array}$ & $\begin{array}{l}\text { Legs flaccid. } \\
\text { Trunk and right arm } \\
\text { improved }\end{array}$ \\
\hline 3 & 5 mths. & $\mathbf{M}$ & Irritable & $\begin{array}{ll}P & 50 \\
C & 56 \\
S & 60\end{array}$ & Legs & $\begin{array}{l}\text { Right leg improved. } \\
\text { Left leg flaccid }\end{array}$ \\
\hline 4 & $3 \frac{1}{2} \mathrm{mths}$ & $\mathbf{F}$ & Irritable & $\begin{array}{lc}\text { P } & 70 \\
\text { C } & \text { Blood } \\
\text { S } & 60\end{array}$ & $\begin{array}{l}\text { Neck } \\
\text { Left arm and } \\
\text { shoulder } \\
\text { Both legs }\end{array}$ & $\begin{array}{l}\text { Legs probably normal. } \\
\text { Arm and shoulder weak }\end{array}$ \\
\hline 5 & 5 mths. & $\mathbf{M}$ & Irritable & $\begin{array}{lc}P & 40 \\
C & 214 \\
S & 52 \cdot 5\end{array}$ & $\begin{array}{l}\text { Neck } \\
\text { Both arms }\end{array}$ & Complete recovery \\
\hline 6 & 4 mths. & $\mathbf{F}$ & Irritable & $\begin{array}{ll}P & 50 \\
C & 36 \\
S & 40\end{array}$ & Left arm & No change \\
\hline 7 & 5 weeks. & $\mathbf{M}$ & $\begin{array}{l}\text { Vomiting } \\
\text { Pyrexia }\end{array}$ & $\begin{array}{lr}\mathrm{P} & 90 \\
\mathrm{C} & 190 \\
\mathrm{~S} & 48\end{array}$ & $\begin{array}{l}\text { Intercostals } \\
\text { Both arms } \\
\text { Partial legs }\end{array}$ & $\begin{array}{l}\text { Died. } \\
\text { Bronchopneumonia in } \\
\text { convalescence }\end{array}$ \\
\hline 8 & 5 mths. & $\mathbf{F}$ & $\begin{array}{l}\text { Irritable } \\
\text { Vomiting } \\
\text { Pyrexia }\end{array}$ & $\begin{array}{ll}P & 60 \\
C & 40\end{array}$ & $\begin{array}{l}\text { Neck } \\
\text { All limbs }\end{array}$ & $\begin{array}{l}\text { Arms improved. } \\
\text { Legs little changed }\end{array}$ \\
\hline 9 & 5 weeks & $\mathbf{M}$ & $\begin{array}{l}\text { Anorexia } \\
\text { Pyrexia }\end{array}$ & $\begin{array}{ll}\text { P } & 200 \\
\text { C } & \text { Blood } \\
\text { S } & 48\end{array}$ & $\begin{array}{l}\text { Both legs } \\
\text { Right arm }\end{array}$ & $\begin{array}{l}\text { Legs flaccid } \\
\text { Arm improved }\end{array}$ \\
\hline 10 & 16 days & $\mathbf{M}$ & Off feeds & $\begin{array}{lr}P & 100 \\
C & 130 \\
S & 53\end{array}$ & $\begin{array}{l}\text { Both arms } \\
\text { Intercostals }\end{array}$ & Died 9th day \\
\hline
\end{tabular}

and their occurrence, in Case 10, makes this case unique.

Association of Paralysis and Injections. None of the 10 cases reported had been immunized against diphtheria or pertussis, but in three cases there was a possible relationship between the site of paralysis and a previous recent injection.

Cases 7 and 9 had penicillin injections during the initial pyrexial period of their illness and subsequently developed paralysis of the thighs, the site of the injections. Case 4, N.P., had been vaccinated six weeks before the onset of the illness and developed paralysis of the left arm and shoulder.
Three cases of poliomyelitis following vaccination have been reported (Jermulowicz, 1930; Banerjea, 1935). In the two cases described by Jermulowicz permanent flaccid paralysis developed in the left arm and shoulder girdle 11 and 14 days respectively after vaccination. There was no sensory loss. No other cases of poliomyelitis were seen in the district for three months after these cases occurred. Banerjea's case, a child of 1 year 10 months, developed a flaccid quadriplegia, without sensory loss, 35 days after vaccination which had been performed with two insertions in each arm. She subsequently recovered function in the right arm. No other children in the family developed any 
TABLE 3

Seasonal Incidence of Infantile Cases and of Cases admitted during the Same Perrod

\begin{tabular}{|c|c|c|c|c|c|c|c|c|c|c|c|c|c|c|}
\hline & & Jan. & Feb. & Mar. & Apr. & May & June & July & Aug. & Sept. & Oct. & Nov. & Dec. & Total \\
\hline Series ... & $\ldots$ & & & & 3 & 2 & 2 & 1 & 1 & 1 & & & & \\
\hline All ages & $\ldots$ & 1 & 1 & 4 & 9 & 17 & 43 & 59 & 52 & 38 & 12 & 7 & & 243 \\
\hline
\end{tabular}

illness although two of them were vaccinated at the same time.

Seasonal Incidence. Table 3 shows the seasonal incidence of the infantile cases and that of cases of all ages admitted to hospital during the same period.

Treatment. In the initial stages of the illness all cases were sedated, usually with bromide, and those able to be moved had, at least once a day, a hot bath with passive movements, within the limits of pain. After two weeks a comprehensive muscle survey was made on each patient by an orthopaedic surgeon. Physiotherapists, working under the direction of the surgeon, then initiated active and passive movements using heat and splints as indicated.

Results. Only one case, No. 5, can be regarded as having completely recovered. The others were disappointing, for, despite movements, splints and massage, muscle wasting developed rapidly and contractures often followed because of the difficulty in maintaining good position, splints being badly tolerated at this age. Three of the patients died.

\section{Summary}

Ten cases of poliomyelitis in infants under the age of 6 months are described in detail. These occurred during the 1950 epidemic in Northern Ireland.

The post-mortem findings in one case which had convulsions are summarized.

The symptoms and signs are discussed.

I wish to express my thanks to Dr. F. F. Kane for permission to publish these cases, to Dr. A. R. Crawford for the post-mortem report, and to Dr. G. W. F. Tinsdale for the C.S.F. reports.

\section{REFERENCES}

Aycock, W. L. and Kramer, S. D. (1930). J. exp. Med., $52,457$.

Baneriea, J. C. (1935). Indian J. Paediat., 2, 177.

Baskin, J. L., Soule, E. H. and Mills, S. D. (1950). Amer. J. Dis. Child., 80, 11.

Biermann, A. H. and Piszczek, E. A. (1944). J. Amer. med. Ass., 124, 296.

Gunewardene, T. H. (1918). Lancet, 2, 847.

Jermulowicz M. (1930). Rev. neurol., Paris, 37, (1) 92.

Mouton, C. M., Smillie, J. G. and Bower, A. G. (1950). J. Pediat., 36, 482.

Ward, R., Horstmann, D. M. and Melnick, J. L. (1946). J. clin. Invest., 25, 284. 